the meeting, referred to the loss the Institution had sustained by the lamented death of its patron, His Majesty King George V. At a recent general monthly meeting it was announced that His Majesty King Edward VIII had been graciously pleased to grant his patronage to the Institution. The Visitors' Report referred to the increased attendance at the lectures of late. The recent course of Christmas Juvenile Lectures, given by Dr. Kenneth Mees on Photography, had an average audience of 515, and a Friday Evening Discourse given by Sir James Jeans on November 29 had an attendance of 640 , the largest at the Institution for many years. The Dewar research fellowship, set up under the will of the late Lady Dewar, has been filled by the appointment of Mr. A. R. Ubbelohde, lately senior scholar of Christ Church, Oxford, as the first Dewar fellow. Mr. Ubbelohde has begun investigations on the changes in the palladium lattice caused by the presence of hydrogen, as measured by X-rays, and on the latent heat of sublimation of chain compounds.

PART of the Brown legacy of between $£ 25,000$ and

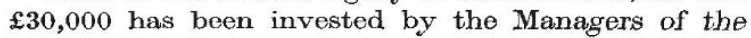
Royal Institution in the purchase of the freehold of No. 19, Albemarle Street, immediately adjoining the premises of the Institution. The purchase has been made in anticipation of future expansion of the research and other activities; but for the present, only the top two floors of the house have been occupied for Institution purposes. The remainder is being let on lease. The reconstruction of the principal library and the rooms below, which the Managers were compelled to undertake last year, is still in progress; and is expected to be completed during the summer. The large new research laboratory in the basement, the construction of which has been made possible by these alterations, promises to be a most valuable improvement. During the year, the publication by the Institution of "Faraday's Diary" has been completed by the issue of vol. 7 and a separate index volume. The Treasurer's report and accounts show a sound and satisfactory position, with substantial additions to the funds during the year despite the heavy cost of the library reconstruction scheme. This reconstruction has caused an interruption in the research work in progress with the large $\mathbf{5 0} \mathrm{kva}$. X-ray generator; but in other researches there has been considerable progress, as the report of the Committee of the Davy Faraday Research Laboratory shows. X-ray structure determinations, related chemical and magnetic problems, the optical study of methane, the construction of a hydrogen liquefier and the ether drift experiment are some of the experimental investigations referred to in the report. The following officers were elected for the year 1936-37 : President, Lord Eustace Percy; Treasurer, Sir Robert Robertson; Secretary, Major Charles E. S. Phillips.

\section{Salaries in the Civil Service}

AT the annual general meeting of the Institution of Professional Civil Servants held on April 30, the president, Sir Richard Redmayne, referred to the inadequacy of the remuneration of the highest posts in the specialist departments of the Civil Service. $\mathrm{He}$ directed attention to the recommendations made by the Royal Commission in 1931 that a salary of $£ 2,500$ should be paid to the Engineer-in-Chief in the Post Office, and that there should be "a certain number of posts carrying an inclusive salary of $£ 2,000$ a year", and to the fact that these recommendations have not yet been carried into effect. $\mathrm{He}$ also pointed out that the Committee on the Staffs of Government Scientific Establishments in 1930 commented on the inadequacy of the prospects offered for the higher posts in the scientific establish. ments, and recommended that a small ad hoc com. mittee should be appointed to consider these posts. In spite of this recommendation no action has been taken. Sir Richard claimed that the placing of the directing posts in the professional, scientific and technical departments on some degree of equality of status and remuneration with those obtaining on the non. technical side of the Service would conduce to that greater efficiency of the Service, which it is the primary aim of the Institution to promote. Sir Richard referred to the recent vote in the House of Commons on the question of equal pay for equal work as between men and women. He stated that the Institution is an unqualified supporter of the principle of equality.

\section{Rockefeller Foundation and International Health}

THe annual report for 1934 of the International Health Division of the Rockefeller Foundation, recently issued, gives an account of the world-wide activities of the Foundation in the field of public health. The projects in operation for which grants are made are broadly speaking of three types : (1) the control of specific diseases, (2) aid to Governments to establish public health on a permanent basis, and (3) public health education. Under the first-named, investigations upon the control of yellow fever have resulted in the discovery in South America of a type of rural or jungle yellow fever, which differs from the usual form in that it is not conveyed by the yellow fever mosquito, which is completely absent in such districts. How this form of yellow fever is conveyed to man is at present unknown. Malaria, hookworm disease, yaws, diphtheria and tuberculosis are some of the other diseases that are the subject of investigation. Foundation aid has been granted to the Bureau of Hygiene and Tropical Diseases of the British Colonial Office, to the Irish Free State and to the United Provinces, India, for local health ser. vices, and to the Calcutta school of public health. The total expenditure for the year amounted to $2,433,535$ dollars. The volume is illustrated with a number of interesting plates.

\section{Recent Acquisitions at the Geological Survey and Museum}

THE gemstone collections of the Geological Survey and Museum have been recently enriched by a number of valuable presentations by H.M. Queen Mary. These include a large polished and carved block of yellow amber weighing 26 ounces, probably from the Prussian coast of the Baltic Sea; an exceptionally 